\title{
Restorative Justice for Blasphemy in Indonesia: Study on the Application of the PNPM Law No. 1 of 1965
}

\author{
Eva Achjani Zulfa \\ University of Indonesia \\ Email: evazulfa@ui.ac.id
}

\begin{abstract}
As is known, the issue of blasphemy in Indonesia became sticking out and rife after the Al Maidah 51 blasphemy case committed by former DKI Jakarta Governor Basuki Tjahaya Purnama or better known to Ahok, continued with event 212 which became an essential moment in the development of the case other blasphemy cases. The concern is how relevant institutions and the ministry of religion are government representatives react in handling these cases. Because in reality, all these cases always end up in prison. Is this the right solution. This study aims to analyze the role of restorative justice in the handling of blasphemy cases in Indonesia. This research uses a qualitative approach with the literature study method in analyzing this problem.
\end{abstract}

Keywords: Restorative Justice, Blasphemy of Religion, Human Rights, Laws.

\section{A. INTRODUCTION}

The blasphemy issue in Indonesia became sticking out and rife after the "Ahok" case, which continued with 212 events, which became an essential moment in the development of subsequent blasphemy cases. Not that there are no such cases. The Mosadek case, Ria Eden, and some other cases have occurred but were not the case raised by the media as impressive as the Ahok case, despite having the same evidentiary value.

The exciting thing from learning about blasphemy cases that occur in Indonesia is how related institutions, namely law enforcement, religious institutions, and even ministries of religion, which are government institutions that should handle these issues, react. Because in reality, almost all cases of blasphemy end in punishment and imprisonment. The question that arises then is whether prison is the answer to the problem of blasphemy in Indonesia?

In the case of Mosadek, who claimed to be Abraham's descendant and made a book that resembled the Qur'an, perhaps one would agree with the view of blasphemy on religion, which is naturally applied in this case. Likewise, Lia Eden tried to mix up several belief systems according to her version. But what about cases that are often interpreted as expressions of hatred or momentary emotional feelings as outlined in 
social media, for example. Or is the Ahok case interpreted as blasphemy after being edited by Buniyani and spread on social media?

Blasphemy can't be separated from the views or ideas relating to a person's belief system or belief that are often clashed with "rights to belief" and "right to the expression" in the view of human rights guaranteed as human rights inherent in a person. Referring to this clash, then the writer's real view is not a severe case to separate which actions are part of the expression of the right to freedom of religion and expression based on human rights views and which are crimes of blasphemy in religion in the (criminal) view of the law.

The right to personal freedom is the right of individuals to express their views and belief systems in their daily personal lives as private rights that must be respected. However, if such matters enter the public sphere, where this is in contact with the belief systems and views of others, then the State's right to regulate it must be present in maintaining order and comfort in social life. Including the arrangement in the legislation.

In this case, the study of history applies the provisions of Law No. 1 PNP of 1965 became interesting to study in connection with the adoption process into Article 156a of the Criminal Code and Article 28 of the ITE Law which was only partially affected so that it changed the interpretation of the provisions and the handling of violations. The qualitative approach and study of the decision are the instruments used in analyzing the problems in this paper.

\section{B. METHOD}

This study uses a qualitative approach using a literature study method that uses secondary data with the qualitative analysis to describe the development of an understanding of restorative justice for blasphemy.

\section{RESULT AND DISCUSSION}

The main problem that is present in handling cases of blasphemy is not a matter of upholding human rights but on the problem of how to deal with crimes related to one's belief system or ideology. Beccaria, in his book "de dellite et de pene" states that handling crimes related to ideology or belief systems cannot be faced with even severe punishment (Beccaria, 1996). Beccaria probably learned from the various convictions of one's belief system from the history of the condemnation of Socrates, Galileo Galilei or many other scientists who had different views with the people of their time, so that people at that time considered their views to be distorted. But severe penalties such as the threat of capital punishment can't even change the views of people who believe in that view. 
In general, the development of the approach to handling criminal cases uses a retributive approach, but on a practical view that emphasizes the usefulness gained from a criminal case management process. Retributive real/absolute consequences that must exist as a retaliation to the perpetrators of criminal acts. Criminal sanctions are described as a gift of suffering, and the officer can be declared a failure if the convicted person does not felt the pain. The classical teaching of this theory is described as the teaching of revenge through lex talionis (in the Old Testament it is described as eyes for eyes, life for life, tooth for tooth, hand for hand, foot for foot, burn to burn, wound to wound, strife for strife ). Hugo Grotius described this theory as malus passionis propter malum actionis (an evil to be inflicted because evil has been committed) Schaefer, (1995) because the success criteria of such a model are suffering or pain because crime is a form of compensation for crimes that have been committed (Immanuel Kant in Muladi et al., 1984).

The purpose of imposing criminal sanctions in handling these crimes is to change the system of beliefs deemed deviant not to deviate. Because of the philosophy of punishment that is wanted is the deterrence effect or deterrent effect and prevention of the next offender candidate. Utilitarian Bentham argues that the aims of the crime are (Bentham in Muladi et al., 1984):

(1) Prevent all violations (to prevent all offenses);

(2) Preventing the evilest violations (to avoid the worst offenses);

(3) Pressing crime (to keep down mischief);

(4) Reducing losses/costs to the smallest (to act the least expensive).

Muladi and Barda Nawawi quoted Bentham's views as saying that harsh crimes were accepted because of reforming effects. However, he acknowledged that serious crimes must be received by the people before they are enforced or defective. The reason for incorporating Bentham's view is on the reasons he stated that criminal law should not be used as a means of retaliation against criminals but only to prevent the occurrence of crime (Bentham in Muladi et al., 1984).

After the development of a criminal orientation which places the victim as an essential part of the goal of punishment, the development of thinking about criminal proceedings then moves towards a new direction where the settlement of criminal cases is a matter that benefits all parties as well as being the most up-to-date discourse thought by people today. Restorative justice is offered as an approach that is considered to be able to meet these demands. Restorative justice is a form of a new frame in looking at the criminal function deeper where the meaning that criminal law is placed as the last shield in social policy must be interpreted in terms of its formulation (legislation), law enforcement (including procedural administration procedures) and consideration of imposing sanctions Criminal offenses (Zulfa, 2009). This becomes a theoretical foothold 
to re-discuss the handling of blasphemy cases, all of which always lead to imprisonment. So that other approaches need to be taken in handling cases of blasphemy.

\section{From Law pnp No. 1 of 1965 to Article 156a of the Criminal Code}

The development of the offense of blasphemy has developed since 1965. At the request of Islamic organizations at that time due to the rise of streams of belief in Indonesia In 1965, (Amnesty International, 2014), the Government of Indonesia issued Presidential Decree No. 1 of the PNPS in 1965 concerning Prevention of Misuse and Blasphemy of Religion (known as the "Law on Blasphemy of Religion").

The contents of Law No. 1 of the 1965 PNPS concerning the Prevention of Abuse and Blasphemy of Religion (known as the "Law on Blasphemy of Religion") consists of several articles but contain the basic norms regarding acts of blasphemy on religion in Article 1 and Article 4. While Article 2 and Article 3 of Law Number 1 of PNPS in 1965 regulates the mechanism of countermeasures and sanctions against violations of the norms contained in article 1. The acts prohibited in Article 1 of Law Number 1 of PNPS in 1965 are that every person It is forbidden to deliberately publicly tell, encourage or seek public support, to interpret a religion that is held in Indonesia or to carry out religious activities that resemble the religious activities of that religion, interpretation, and activities which deviate from the main points of the teachings. That religion. While Article 4 is a provision that adds to Article in the Criminal Code where Article 156a provisions are held, the formulation often reaps various interpretations because it contains two points of action which are often interpreted as an alternative or cumulative formulations of prohibited acts where the perpetrators who deliberately publicly express their feelings or do the deed:

a. which is hostility, abuse or desecration of a religion that is adopted in Indonesia;

b. with the intention that people do not follow any religion based on the Almighty God."

The exciting thing from the above provisions is that this law only mandates the existence of one article provision, which adds provisions in the Criminal Code, namely Article 4. While Article 1, which becomes a primary offense in this provision, is not mandated to be adopted in the Criminal Code. To this, Oemar Seno Adji, argues that the primary basis on which the inclusion of religious offenses in the Penal Code is the precepts of the Almighty God as the primary cause of the Pancasila state. Therefore, creating an implication if someone commits an act of contempt or blasphemy against the religion and God being worshiped, it cannot be left without punishment. Thus, by seeing Godhead as the central point of state life, the offense of blasphemy as 
"blasphemy" becomes a priority in religious offenses (ELSAM, 2007). This provision changes the view on the offense of insulting to the groups stipulated in Article 156 of the Criminal Code.

What is often a public question, especially is the difference between these two provisions, namely Article 1 and Article 4 can be drawn from the following comparison table:

\begin{tabular}{|c|c|c|}
\hline & Article 1 & Article 4 \\
\hline Form of mistake & deliberately in public & On purpose in public \\
\hline Prohibited acts & $\begin{array}{l}\text { - tell, } \\
\text { - recommend or } \\
\text { - seek general support, } \\
\text { to do: } \\
\text { - interpretation of } \\
\text { something that is adhered } \\
\text { to in Indonesia or } \\
\text { - carrying out religious } \\
\text { activities that resemble the } \\
\text { religious activities of that } \\
\text { religion, } \\
\text { which interpretations and } \\
\text { activities deviate from the } \\
\text { main points of the religious } \\
\text { teachings. }\end{array}$ & $\begin{array}{l}\text { issuing feelings or doing } \\
\text { actions: } \\
\text { a. which is hostility, abuse } \\
\text { or desecration of a religion } \\
\text { that is adopted in } \\
\text { Indonesia; } \\
\text { b. with the intention that } \\
\text { people do not follow any } \\
\text { religion, which is based on } \\
\text { the Godhead." }\end{array}$ \\
\hline
\end{tabular}

Comparing the two provisions, basically the core difference between Article 1 and Article 4 of Law Number 1 PNPS 1965 is

a. that Article 1 places more emphasis on the deeds of particular religions which are misleading because they differ from the teachings of those religions, while Article 4 places more emphasis on feelings of hostility towards one particular religion.

b. Whereas Article 4 formulates an alternative act in which this provision threatens other actions in the form of propaganda not to believe in religion.

Referring to this difference, Oemar Seno Adji's view states that what is intended to be protected in the concept of "offense against religion" is the purity of religion itself. Because according to its designers, religion needs to be protected from the possibilities of actions of people who can denigrate and defame religious symbols, such as God, the Prophet, the Scriptures. Not protecting the religious freedom of the adherents (individuals) becomes somewhat biased when associated with Article 4 point b, which prohibits people from not having religion as part of religious freedom. In the view of Human Rights, as a non-derogable rights or rights that cannot be ruled out, this 
restriction causes those who believe not to have a religion to have no place in Indonesia. Regardless of whether then this becomes one of the politics of criminal law at the time, this law was formed into another study that will not be discussed in this paper.

\section{Forgotten Diversity}

The exciting thing to study further is that by including the provisions of Article 4 of Law Number 1 PNPS of 1965, the other provisions of this law are forgotten. Even though the norms that are in it have never been declared revoked. So in many cases handled it all ended up in prison, as the following table:

\begin{tabular}{|c|c|c|c|}
\hline Year & Case & Name & Sentences \\
\hline 1968 & $\begin{array}{l}\text { Short story: } \\
\text { Langit Makin } \\
\text { Mendung }\end{array}$ & HB Jassin & One year trial \\
\hline 1990 & Monitor & Arswendo & Prison 4 Years 6 Months \\
\hline 2006 & $\begin{array}{l}\text { revelation } \\
\text { from Gabriel }\end{array}$ & $\begin{array}{l}\text { Lia Aminuddin aka } \\
\text { Lia Eden }\end{array}$ & Prison 2 years \\
\hline 2009 & $\begin{array}{l}\text { revelation } \\
\text { from Gabriel }\end{array}$ & $\begin{array}{l}\text { Lia Aminuddin aka } \\
\text { Lia Eden }\end{array}$ & Prison 3 years \\
\hline 2008 & Gafatar & Musadek & Prison 4 years \\
\hline 2016 & Gafatar & Musadek & Prison 5 years \\
\hline 2015 & Hindu Religion & $\begin{array}{l}\text { Nando Irawansyah } \\
\text { M'ali }\end{array}$ & customary sanctions \\
\hline 2015 & Hindu Religion & Rusgiani & Prison 14 months \\
\hline 2016 & $\begin{array}{l}\text { Surat Al } \\
\text { Maidah } 51\end{array}$ & $\begin{array}{l}\text { Basuki Tjahaya } \\
\text { Purnama alias } \\
\text { Ahok }\end{array}$ & Prison 2 years \\
\hline 2018 & Poetry & Sukmawati & $\begin{array}{l}\text { Notification of termination } \\
\text { of investigation (SP3) }\end{array}$ \\
\hline
\end{tabular}

The table above, except for Sukmawati, who received SP3 or the cessation of the investigation and ando Irawansyah $\mathrm{M}^{\prime}$ ali, who received customary sanctions, the rest led to the threat of imprisonment. But the question is whether prison is a powerful drug 
in handling this case? In the table above, the lightest sentence was given to HB Jassin in 1968, shortly after Law No. 1 PNPS of 1965 was issued. While others above one year in prison. And when referring to Lia Eden and Musadek, where residuals or crimes can be repeatedly stated, prison is not the answer.

The provisions of Article 2 of Law No. 1 of the PNPS of 1965 actually provide an alternative treatment for deviant acts. In the Lia Eden Case, Confess as a Mahdi priest who gets revelations from the angel Gabriel and meets the Virgin Mary. In the case of Gafatar, it is not much different. Gafatar is known to be a metamorphosis of al-Qaidah al-Islamiyah's teachings, where the learning has been banned since 2007 because it was judged heretical. Besides the metamorphosis of al-Qaidah al-Islamiyah, the MUI found at least three points that made Gafatar declared heretical, namely the characterization of Musaddeq as a savior after the Prophet Muhammad. The MUI's findings can be stated as a form of teaching deviation that needs to be addressed.

So in connection with the heresy of the teaching, the form of handling in Article 2 paragraph (1) is stated to be given in the form of orders and stern warnings to stop the action in a joint decision of the Minister of Religion, Minister / Attorney General and the Minister of the Interior. Where in Paragraph (2) is carried out by an organization or something of a creed, the President of the Republic of Indonesia can dissolve the organization and declare the organization or sect as a prohibited organization/sect, one after the President is considered by the Minister of Religion, the Minister / Attorney General and the Minister of the Interior.

In this case, the provisions of the law give authority (discretion) to law enforcement by coordinating with the Minister of Religion, the Minister / Attorney General and the Minister of the Interior to use non-criminal means (non-penal), namely through administrative actions in the form of termination and prohibition of the teaching, which is the author's view, which should be continued with the process or efforts of coaching from the relevant institutions to prevent the repetition of this case. This approach is known as a form of restorative justice, which was started by Garvey to respond to crime.

The pattern of formulating a law that uses a restorative justice approach through diversion (Zulfa, 2009), or transferring cases handling outside the criminal justice system becomes interesting to explore considering this approach was not yet popular when the Undnag-Number 1 / Pnp / 1965 was made. The objective of this action is awareness and recovery of the condition of error from the understanding of religious teachings that are considered wrong. This should be the realm of the ministry of religion. While the use of criminal law facilities, as stated in Article 3, is the last resort or the maximum means when maximum efforts in the form of prohibition and guidance have been made but repetition or residing still occurs. 
As in the table above, the pattern of handling is illustrated by the handling of the HB Jassin case through trial, criminal sanctions (conditional criminal), Nando Irawansyah M'ali through forgiveness and traditional sanctions and Sukmawati where forgiveness and guidance as promised by the MUI into the application of Diversi in this case . (EAZ).

\section{CONCLUSION}

Of all the blasphemy cases in Indonesia, almost all ended up in prison, except for the trials experienced by Sukmawati. They were in SP3 or the Ando Irawansyah M'ali case, which ended with adat sanctions. This shows that the penalties for blasphemy have tended to be a means of avenger and not to prevent how crime did not occur. Restorative justice is offered as a form of approach to the resolution of criminal cases that benefit both parties. The pattern of approach to solving cases outside the religious justice system by involving relevant institutions can be considered.

\section{REFERENCES}

1. Adji, O. S. (1990). Delik Pers di Indonesia. Jakarta: Erlangga.

2. Amnesty International. (2014). Mengadili Keyakinan: Undang-Undang Penodaan Agama Indonesia. Retrieved from https://www.amnesty.org/download/Documents/208000/asa210182014in.pdf.

3. Beccaria, C. (1996). Of Crime and Punishment. Oxford: Oxford University Press.

4. Bangka.tribunnews.com. (2017). Selain Kasus Ahok, Inilah Kasus-Kasus Penistaan Agama di Indonesia. Retrieved from http://bangka.tribunnews.com/2017/05/09/selainkasus-ahok-inilah-kasus-kasus-penistaan-agama-yang-menghebohkan-diindonesia?page $=2$.

5. Constitutional Court of the Republic of Indonesia, Decision Number 140 / PUU-VII / 2009.

6. Constitutional Court of the Republic of Indonesia, Decision Number 97 / PUU-XIV / 2016.

7. Djafar, W., \& Abidin, Z. (2014). Membelenggu ekspresi: studi kasus mengenai praktik pemblokiran/penyaringan konten internet dan kriminalisasi pengguna internet di Indonesia. Elsam.

8. ELSAM. (2007). Perkembangan Konsep Tindak Pidana Terkait Dengan Agama dalam Pembaharuan KUHP. Aliansi RKUHP. Jakarta: ELSAM.

9. Ijcr.or.id. (2017). Tren Penggunaan Pasal 28 ayat (2) ITE terkait Penyebar Kebencian Berbasis SARA Akan Meningkat. Retrieved from http://icjr.or.id/tren-penggunaanpasal-28-ayat-2-ite-terkait-penyebar-kebencian-berbasis-sara-akan-meningkat/. 
10. Lamintang, P. A. F., \& Lamintang, T. (2010). Delik-Delik Khusus Kejahatan Terhadap Kepentingan Hukum Negara. Jakarta: Sinar Grafika.

11. Miftahusurur \& Sumamiharja. (2007). Delik-delik Keagamaan di dalam RUU KUHP Indonesia, Jakarta: DESANTARA.

12. Moeljatno. (1996). Kitab Undang-undang Hukum Pidana. Jakarta: Bumi Aksara.

13. Muaro District Court, Verdict No. 45 / PID.B / 2012 / PN.MR.

14. Mudzakkir. (2010). Tindak Pidana Terhadap Agama Dalam Kitab Undang-undang Pidana (KUHP) dan Undang-Undang Nomor 1/Pnps/1965 tentang Pencegahan Penyalahgunaan dan/atau Penodaan Agama (Kajian Terhadap Praktek Penegakan Hukum dan Prospek Pengaturannya Dalam Hukum Positif Indonesia), Jakarta: Pusat Perencanaan Pembangunan Hukum Nasional Badan Pembinaan Hukum Nasional Kementerian Hukum dan Hak Asasi Manusia.

15. Muladi, \& Arief, B. N. (1984). Teori-Teori dan Kebijakan Pidana. Bandung: Alumni.

16. Praja, J. S., \& Syihabuddin, A. (1982). Delik Agama dalam Hukum Pidana di Indonesia. Bandung: Angkasa.

17. The Supreme Court of the Republic of Indonesia, Decision Number 71K/KR/1973.

18. Schaefer, U. (1996). Crime and punishment i. Law and International Order.

19. Walgrave, L. (2001). On restoration and punishment: favorable similarities and fortunate differences. Restorative justice for juveniles: Conferencing, mediation and circles, 17-37.

20. Zulfa, E. A., (2009). Keadilan Restorative di Indonesia. (Doctoral Dissertation University of Indonesia). 